\title{
Consuming Slavery, Performing Cuba: Ethnography, Carnival and Black Public Culture ${ }^{1}$
}

\author{
Professor Lisa Maya Knaver, University of Massachusetts
}

Anthropologist Michel-Ralph Trujillo notes that "any historical narrative is a particular bundle of silences." ${ }^{2}$ This article explores the silences and gaps around slavery and its legacy in the historical narratives that animate Cuba's heritage landscape and inform cultural performances. I argue that the ways slavery is, and, more tellingly, is not represented at heritage sites, and in State-sponsored cultural performances provides a lens for examining a larger ambivalence concerning race in the Cuban national imaginary. ${ }^{3}$ Rather than focusing on slavery as a mode of institutionalized violence, a set of social relations, and ideological structures, Cuban heritage narratives, cultural productions and visual representations highlight cultural contributions made by peoples of African descent to Cuban national identity. ${ }^{4}$ While slave resistance is sometimes mentioned or enacted, racism and race are usually relegated to a fairly distant past. Cuban narratives thus downplay the racialized history of the nation and instead promote an inclusive, post-racial nationalism. It is as though enslaved people left an imprint, while the institutions, social relations and ideologies responsible for their enslavement vanished without a trace.

In particular, I want to interrogate the intricate and dialectical interplay between two modes of cultural presentation that Cuban cultural institutions deploy in their treatment of Black culture that I call "the ethnographic" and "the carnivalistic". "The ethnographic" is a form of cultural presentation that purports to be historically and cultural accurate or authentic (itself a problematic concept), often drawing upon ethnographic research. "The carnivalistic" emphasizes spectacle, staging, and theatricalization. These are not, I argue, mutually exclusive or separate endeavors, cleanly distinguished in time, space, or sponsorship, but can be competing or even complementary impulses that inform a single museum display or music and dance performance. Nor are they the exclusive province of State cultural functionaries, although most of the icons and performances I discuss are produced and circulated with at least the tacit permission of the State, if not direct State sponsorship. Performers, vendors and ordinary citizens, in Cuba as elsewhere, can adopt these modes of selfpresentation for strategic or other reasons.

My analysis is based on a close reading of two sets of cultural productions. ${ }^{5}$ First, I look at the circulation and consumption of a series of inanimate objects representing Black people and Black culture in Cuba - principally dolls, small statues and carvings found at tourist sites and throughout the heritage landscape - and also how these are animated by Cubans who perform these or similar identities, particularly noting which characters are minimized or silenced in the tourist industry. I also explore how similar icons are consumed and used in everyday settings. I then examine more structured cultural performances that actively encourage the enactment or representation of accepted slave experiences, focusing on an annual re-enactment of a colonial-era "Black carnival" parade. ${ }^{6}$

The theatricalized spectacles seem, at first glance, to occupy a different register than the more ethnographically informed representations in museums or discussions of Black culture in scholarly publications. Yet, I argue, that they are part of a continuum. Each one references, in distinct ways, a lengthy history of popular and high art renditions, folkloricized performances and ethnographic displays of Black-identified cultural forms in Cuba. Since most of these performances and sites come under the aegis of State cultural institutions, they can be seen as efforts to governmentalize and "contain" Afrocuban religion and Black public culture through preservation and re-enactment.7 I suggest that the meanings of these productions are not static, nor are they determined solely by 
cultural and heritage officials. Instead, I view this terrain as a zone of friction, in which the (mostly Black) producers of these cultural performances, audiences as well as everyday Cuban citizens, actively complicate and contest the encoded meanings and create counter-narratives, and use them to advance their own agendas. ${ }^{8}$

To contextualize my discussion of the interplay between race and national identity in present-day Cuba, I start with a brief sketch of the emergence of the tourist economy, including how both race and the commoditization of culture have been shaped by larger dynamics. While Cuba has its own particular constellation of ideologies and debates about racial and national identities, the ironies and frictions I discuss are not unique to the island. Nor is the commoditization of culture, usually combining ethnographic and carnivalistic approaches, a recent development. However, it has become more ubiquitous than ever, and is a hallmark of neoliberalized development strategies and tourist economies in many parts of the world. ${ }^{9}$

\section{Old and new cultural economies of race in Cuba}

Racial ambivalence came into sharp relief immediately following the collapse of the Soviet Union a period of severe economic, social and political crisis in Cuba that the authorities euphemistically labeled "the special period in a time of peace". In the wake of the loss of Soviet economic supports, the Cuban government shifted its economic policies to promote tourism as a source of hard currency to prevent economic collapse and support social spending. While Cuba and its foreign investors have developed numerous "sun and sand" resorts, there have also been efforts to promote cultural (and also medical) tourism. Consequently, the "heritage industry" has exploded as a result of foreign and domestic investment in heritage projects. These include museums, the reconstruction of Habana Vieja (Old Havana) under the aegis of UNESCO "patrimony of humanity" designation, and Cuba's component of the transnational "Slave Routes" project. ${ }^{10}$

By the start of the twenty-first century, tourism revenues accounted for over a third of Cuba's hard currency income. ${ }^{11}$ Although tourism fell off after September 11, 2001, it remains one of the largest sources of hard currency and is a pillar of Cuba's economy. ${ }^{12}$ At the same time, the Cuban government implemented several other market-oriented initiatives, such as re-establishing farmers' markets which allowed farmers to directly sell part of their yield to consumers, ${ }^{13}$ and opened the door for certain kinds of self-employment and independently-owned small businesses. ${ }^{14}$

In 1993, the State legalized the possession of U.S. dollars and allowed ordinary citizens to patronize the hard-currency stores which sold goods not available via the libreta (ration-book); these were formerly limited to diplomats, other foreign visitors and party officials. The government also opened hundreds more hard-currency stores, not only in tourist zones but in ordinary residential neighborhoods in Havana and other cities. The dollarization and marketization of the economy was at the same time an effort to legalize and also regulate and contain the vast informal sector that had sprung up as thousands of Cubans began to inventar (literally, to invent, but often meaning "to hustle"), so that they could resolver (resolve) their economic needs in the wake of the economic collapse. ${ }^{15}$

This growing marketization, combined with increased numbers of both foreign and diasporic tourists, spurred consumption, consumerism, and the commercialization of daily life. ${ }^{16}$ Some of Havana's prerevolutionary shopping streets that had fallen into disuse or disrepair were refurbished and turned back into commercial zones. In residential neighborhoods like Cayo Hueso in Centro Habana (Central Havana), streetscapes featured a mixture of small enterprises, Cuban peso stores and hard-currency stores. ${ }^{17}$ By contrast, streets like Calle Obispo in the tourist zone of Habana Vieja are lined with many upscale boutiques and eateries. 1997 saw the opening of Havana's first multi-story mall - and the first shopping center of any sort to be located in an historically "inner city" neighborhood - the Plaza Carlos III. During my years of field visits to Centro Habana, the mall was usually crowded, with people 
congregating in the downstairs food court and the sidewalk outside the main entrance. Cubans sought not only daily necessities like soap and cooking oil that had been in short supply during the harshest years of the special period but brand-name clothing, electronics and other consumer goods sported by tourists and available at relatively high prices in State-owned hard currency stores (or in the stillvibrant informal economy). ${ }^{18}$ Going to la shopping - Cuban slang for a hard-currency store - became a daily activity and, for many, a form of entertainment. ${ }^{19}$

As hotels, resorts, hard-currency stores and small enterprises have mushroomed, Cuban culture, and especially Black-identified culture, has become increasingly commoditized and packaged for touristic consumption. And herein lie some of the most potent ironies. Recent studies, most notably by Cuba's Centro de Antropología (Anthropology Center), have substantiated what many scholars and others argued earlier based upon anecdotal evidence: that the marketization of Cuba, its rearticulation into the global economy through tourism, assorted joint ventures and remittances, have helped produce new forms of stratification and possibly a nascent class formation, whose contours are influenced by race, gender and geography. Blacks have a harder time finding a foothold in some sectors of what scholars are labeling the "emergent economy" (front-desk jobs in tourism and joint enterprises). Instead, they are hired for more menial jobs in tourism such as chambermaid, waiters, parking attendants, doormen and bellhops. ${ }^{20}$ Blacks receive less remittance money from relatives in the diaspora to finance self-owned businesses, and therefore seek opportunity in the informal sector. Black men are over-represented in the ranks of street hustlers, or jineteros, who frequent tourist locales. Rehearsing racialized (and gendered) tropes that date back over a century, Black women's bodies (and to a degree, Black men's bodies) are highly desirable commodities for foreign tourists seeking sexual adventure. ${ }^{21}$ Black male bodies are still construed as dangerous and disruptive in public space (and commoditized private spaces such as resorts), and Black men are subject to disproportionate surveillance by police and hotel and resort staff.

That race is being discussed at all - the Centro de Antropología's research was covered in Granma, the official Communist Party daily newspaper - represents a shift. However, official discourse largely describes racism as a matter of prejudiced views held by individuals and an unfortunate legacy of the past. It thus sidesteps institutional or structural factors -- such as the historical ambivalence concerning whether Blacks could ever be good Cuban citizens, and the post-revolutionary silencing of discussions of race. ${ }^{22}$

At the same time Blackness has become a desirable commodity in other arenas of the tourist economy. ${ }^{23}$ Cultural practices marked as "Black" - folkloric music, dance and "religions of African origin" - which the authorities formerly frowned upon and discouraged, or sought to convert into vehicles for the promotion of socialist values - have been turned into valuable cultural currency. Foreign and Cuban tour operators offer opportunities to study "traditional" Afrocuban music and dance and observe religious ceremonies. ${ }^{24}$ Some enterprising santeros and santeras (santeria priests and priestesses) and other Afrocuban religious specialists have been able to register their homes as State-recognized cultural centers. ${ }^{25}$ Many performers, artisans, and religious practitioners have thus been able to parlay their expertise (real or ascribed) in Black culture into a means of supporting themselves and their families.

As I detail below, performances, museum displays and tourist souvenirs reinforce deeply embedded racialized and gendered images. For example, Havana's legendary Tropicana nightclub, which dates back to the late 1930 s when Cuba was promoted as a tropical paradise for thrill-seeking foreigners, still presents nightly cabaret performances featuring a chorus line of statuesque and scantily clad mulata (light-skinned Black women) dancers. ${ }^{26}$ The expansion of the tourist industry led to the recent opening of two additional branches of the Tropicana in Cuba's eastern city of Santiago and near the beach resort of Varadero. The music and dance revues at the Tropicana and other cabarets usually 
offer highly stylized and sometimes quite fanciful versions of Black-identified "folkloric" genres like rumba and Afrocuban religious music and dance, ${ }^{27}$ along with guest appearances by more "traditional" performers of Afrocuban folkloric music. Meanwhile, there has been a small explosion of open-air and indoor venues for more "authentic" Afrocuban folkloric music (along with the emergence of several new folkloric ensembles seeking performance opportunities).

The upbeat, celebratory tone of most of these performances, and the emphasis on festive ethnicity, the folkloristic and the performative fit well with the government's promotion of a raceless or racially inclusive nationalism. ${ }^{28}$ Emcees at cultural performances frequently recite José Martí's aphorism, "In Cuba there will never be a race war ... Cuban is more than White, more than mulatto, more than Black..." ${ }^{29}$ The hit song "La Vida es Un Carnaval", popularized on the island by Isaac Delgado, could well serve as a musical version of one of the carnivalistic master tropes deployed by the State tourist industry - a sun-drenched island paradise where people sing their cares away (the song's chorus exhorts the listener, "Ay, there's no need to cry, life is a carnival, and singing will take away your cares." $)^{30}$

The performativity of these varied registers of cultural production - the breathing actors alongside the static icons - must be interpreted within the context of Cuba's heritage landscape, which has been shaped by the intersecting, sometimes complementary and sometimes competing desires, and projects, of global capital, the Cuban State, cultural promoters, cultural producers and performers, everyday Cuban citizens, and tourists. In this contact zone, varied imaginaries and identities are constructed, narrated, negotiated and contested. As Daina Harvey notes in her discussion of Black heritage sites in New Jersey, spaces are experienced differently by tourists and residents. ${ }^{31}$ The promotion of these images, objects and performances by both public and private actors in the tourist and heritage industries speaks volumes about the racialized and gendered cultural economy of contemporary Cuba.

The performative spectacles, both the ethnographic reconstructions and the everyday commoditized enactments, are set within a heritage landscape that avoids mention of racial disharmony, past or present, or, largely, of slavery itself except safely enshrined inside museums, and there usually only obliquely. The idealized quaintness of the restoration of Habana Vieja is itself a kind of Whiteface minstrelsy: it evokes the glory of the Spanish colonial past while never mentioning colonialism. Urban spaces are palimpsests, but historic restorations or reconstructions are always selective in the slices or fragments of the past they chose to recover or recreate; they inevitably omit or suppress certain narratives while reframing and emphasizing others. In selecting one particular historic freezeframe, even the most faithful reproduction (involving legions of archaeologists and architectural historians) ignores everything that preceded or followed it. ${ }^{32}$ History often becomes a vehicle to promote consumption, particularly by foreign tourists. Further, planning decisions are usually made by developers, bureaucrats and experts; present-day residents of the surrounding area are either left out or given limited voice. 33

The Centro Histórico (historic center) of Habana Vieja was restored and reconstructed under the auspices the Office of the City Historian of Havana (referred to herein by its Spanish acronym OHCH). $\mathrm{OHCH}$ is a unique semi-autonomous governmental agency that has been charged with supervising the reconstruction of Old Havana and promoting tourist development. ${ }^{34}$ The Cuban government has given the $\mathrm{OHCH}$ extraordinary powers to raise revenues for reconstruction through tour agencies, commercial ventures, and admission fees to museums, pseudo-museums and historic sites, and to establish joint ventures with foreign companies and governments. 35 The governments of Spain and the Canary Islands (and also Spanish banks) underwrote much of the reconstruction of Habana Vieja, sparking quips that this amounted to a reconquista or reconquest by the former colonial power, a century after independence. 
There is little in the historic center that directly signals the presence of enslaved (and some free) Africans who undoubtedly contributed much of the labor that built the houses, fountains, churches, and laid the paving stones. A recent mural depicting Havana "society" of the nineteenth century includes two or three Black faces (see figure 1). More alarmingly, the whitewashed facades of the majestic Plaza Vieja are narrated by a billboard with a blandly nationalistic quote from José Antonio Saco, the chief promoter of the colonial-era policy of blanqueamiento - whitening Cuba's population through increased Spanish immigration. The specter of Haiti as the world's first free Black republic haunted nineteenth century Cuba, and the explosion of the Black population produced by Cuba's sugar boom stoked racial fears even within the anti-colonialist movement. Saco and many others now heralded as great Cuban nationalists did not want a Cuba libre (free Cuba) with a Black majority. The silencing of this narrative produces a weird kind of kaleidescoping; by ignoring or deleting any mention of these past efforts to literally whitewash Cuba's population, the authors and architects of these and other historic sites also whitewash the racially troubled present, and deflect any suggestion

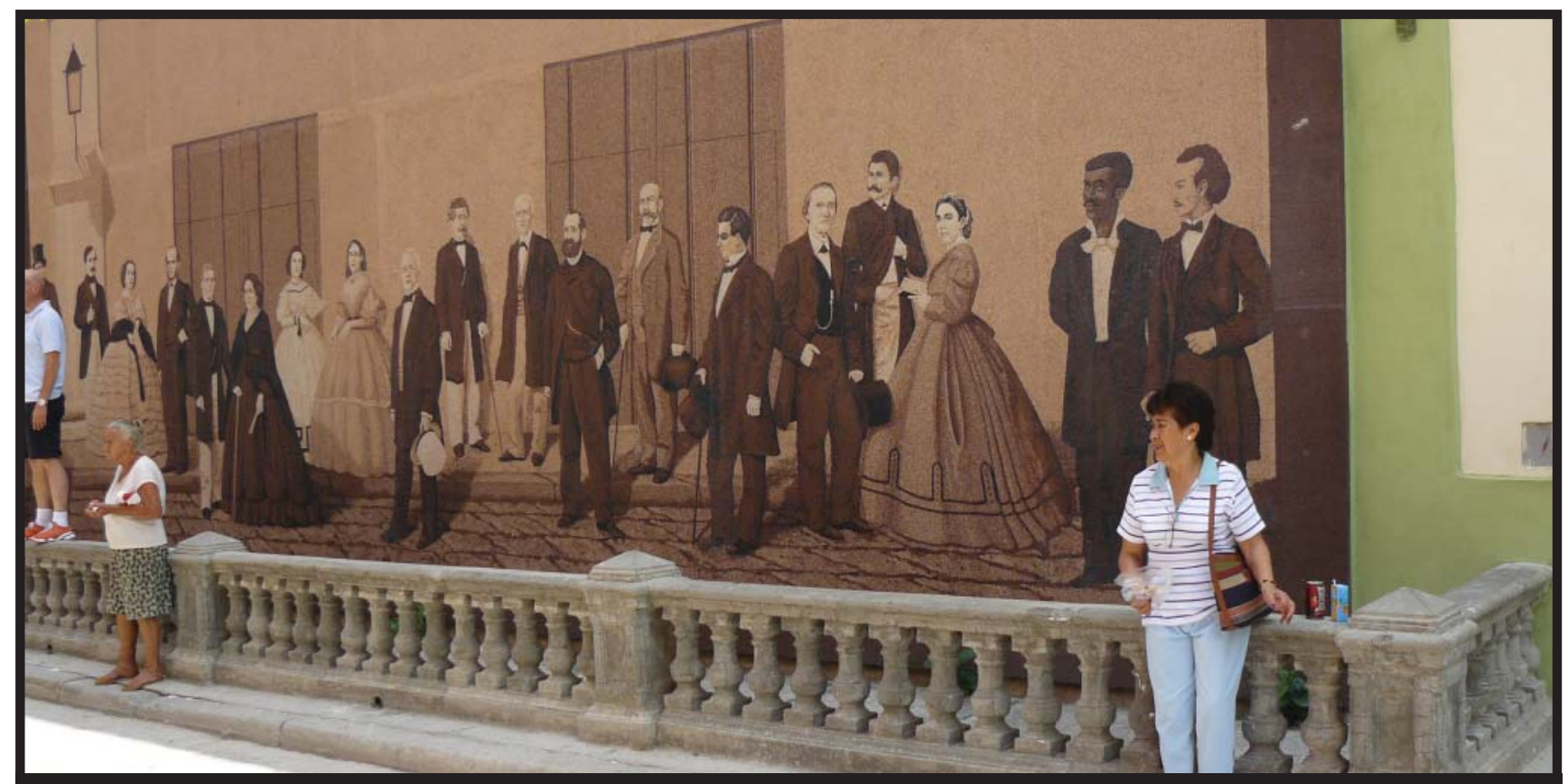

Figure 1: A recently-installed mural depicting nineteenth century Havana society, on a busy pedestrian street in the Centro Histórico

that race continues to be an issue in Cuba. There is nothing in the official signage to unsettle the claim that Cuba is a raceless society.

The absence of direct reference to slavery in Havana's historic (and touristic) center contrasts with the hulking socialist realism of the Monument to Carlota's Rebellion, commemorating a nineteenth century slave uprising (see Figure 2). This imposing sculpture, however, is located in an isolated (although strikingly beautiful) corner of Matanzas province. When I visited in June 2007, accompanied by an official of the provincial Department of Patrimony, we were the only visitors. Cuba participated in the initial UNESCO-sponsored discussions that led to the Slave Routes (La Ruta del Esclavo) initiative, and has identified and inventoried numerous sites of historic significance ruins of plantations, sugar mills, slave barracks or barracones, slave cemeteries, many of which are located well outside of Havana, in what anthropologist Anna Tsing calls "out of the way places"..$^{6}$ The Museum of the Slave Route is housed in the restored Castillo de San Severino, on the outskirts of the city of Matanzas, and is not easily accessible except by automobile or tour bus. ${ }^{37}$ Matanzas boasts 
many beautiful colonial-era buildings and is recognized as a center of Afrocuban religion and music, and it is not far from the resort town of Varadero, but many tourists head straight for the beaches. ${ }^{38}$

\section{Objectifying (and selling) Blackness}

With this contextual sketch, I now turn to the objects and performances. My analysis begins with the nearly ubiquitous figure of a Black female doll I purchased at a tourist shop in Habana Vieja (see figure 4). These dolls, which come in varied sizes, are made of Black cloth and dressed in colonial-era dresses, often covered with an apron. Characteristically, they wear matching headscarves and sometimes golden-colored hoop earrings. The dolls are available from street vendors and at souvenir shops throughout the Centro Histórico, and also at handicraft markets and tourist shops across the island. Similar dolls are sold at tourist sites throughout the Caribbean; when I presented a preliminary version of this article at a conference in Barbados, and held up my Cuban doll, several people asked me if I had purchased the doll in Barbados.

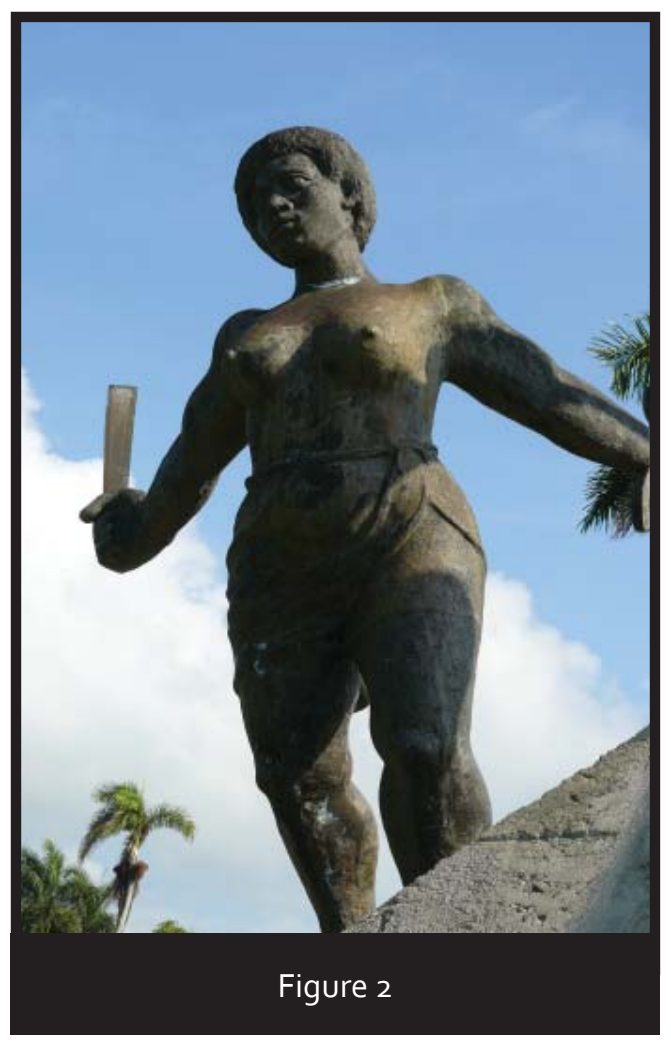

Other images of Blackness are on display and for sale in tourist areas and museums throughout the island. Carved wooden statues, painted ceramic figurines and paintings rehearse other racialized and gendered tropes that are part of both the national and touristic imaginaries: the smiling and everavailable mulata, usually clad in a skin-tight dress emphasizing her ample hips and bosom, which is sometimes barely contained by the dress, and jovial Black men rolling cigars, playing drums or holding serving trays. Some of these figures are relatively realistic, but others are gross caricatures, with bulbous lips, or extravagantly exaggerated breasts and bottoms.

Silenced are the stories of the origins of these figures: their post-colonial minstrelsy has roots in the exoticized caricatures or more romanticized representations of the colonial imaginary: the Blackface theater, negrista literature and costumbrista visual arts that flourished in nineteenth century Havana. ${ }^{39}$ What makes these images problematic is not solely the nature of the tropes themselves, but also the contexts in which they are disseminated. All of the venues where these icons are sold are either licensed or run by State enterprises. Here images of smiling complacency, servility and sexual availability - the enslaved or subordinate status often implied rather than articulated - are juxtaposed with equally exoticized but more generic "African" style carvings that began to appear in Cuba's tourist zones in the 1990s, and other more genuinely national icons such as hand-rolled cigars, bottles of rum and the superficially more rebellious visage of Che Guevara that is endlessly reproduced on t-shirts, caps or newspapers..$^{\circ}$

Vendors, of course, offer what they think the tourists want. But very little takes place in the Centro Histórico without the permission or imprimatur of the Office of the City Historian of Havana. All of the vendors operating in the historic district, whether in stores or stands in the artisans' fair, must be licensed by the $\mathrm{OHCH}$, and the $\mathrm{OHCH}$ 's power to award (or deny) licenses is a source of contention for local residents who want to operate small businesses.

These kinds of carnivalistic figurines and dolls are sold not only in stores and fairs that are clearly commercial and geared towards tourists, but also at gift shops in ostensibly more high-minded museums. Figure 3 shows a shelf in the gift shop at the Museo Histórico de Guanabacoa (the Historical 
Museum of Guanabacoa), a municipal museum with a more serious ethnographic and historical mission, and one that is internationally recognized for its carefully designed and "authentic" dioramic displays of Cuba's religions of African origin..$^{41}$ Similar figures are sold at other equally high-minded museums. ${ }^{42}$

The high-art and commercial originals of these archetypes are on display at the newly refurbished Museum of Fine Arts in Habana Vieja. A small room tucked away off the main exhibition space contains an exhibit devoted entirely to the nineteenth century tobacco marquillas (cigar box labels), lavishly illustrated by some of the most noted artists of the day, often with scenes of plantation and Black urban life; they are a rich source of information about the highly gendered racial economy of colonial Cuba. 43 In addition, there are several paintings by French artist Victor Landaluze, who was celebrated for his colorful and "authentic" depictions of everyday scenes of Black urban life in Cuba. Dandified Black men in brightly colored clothing swagger and flirt with equally resplendent women. Completely absent is any curatorial or critical commentary about costumbrismo, the colonial gaze, or slavery; indeed few works are even labeled. 44

These figures are further complicated by the existence of their real-life counterparts on the streets outside. The sweeping plazas of Habana Vieja, many now restored or refashioned a nearly-pristine colonial-era veneer, are also stages for costumed men and women (mostly women) who seem to have stepped out of the costumbrista canvases inside the museum. In front of Havana's massive seventeenth century cathedral a heavy-set, dark skinned, middle aged woman, sits at a small table and offers spiritual advice and readings. She is dressed in voluminous white skirts and a headscarf, and wears numerous beaded necklaces; for many Cubans and some foreign visitors familiar with Afrocuban religions, these are easily legible symbols of religious affiliation. ${ }^{45}$ She frequently puffs on a fat cigar (which doubles as a national and religious icon) and can be found here year round. There are a few other similarly outfitted women in different sites throughout the Centro Histórico, although none seem quite as emplaced and authoritative as she.

Occupying a slightly different niche in the tourist imaginary are several younger, more nubile women enacting the roles of colonial-era vendors, dressed in colorful flowing gowns, bearing baskets of

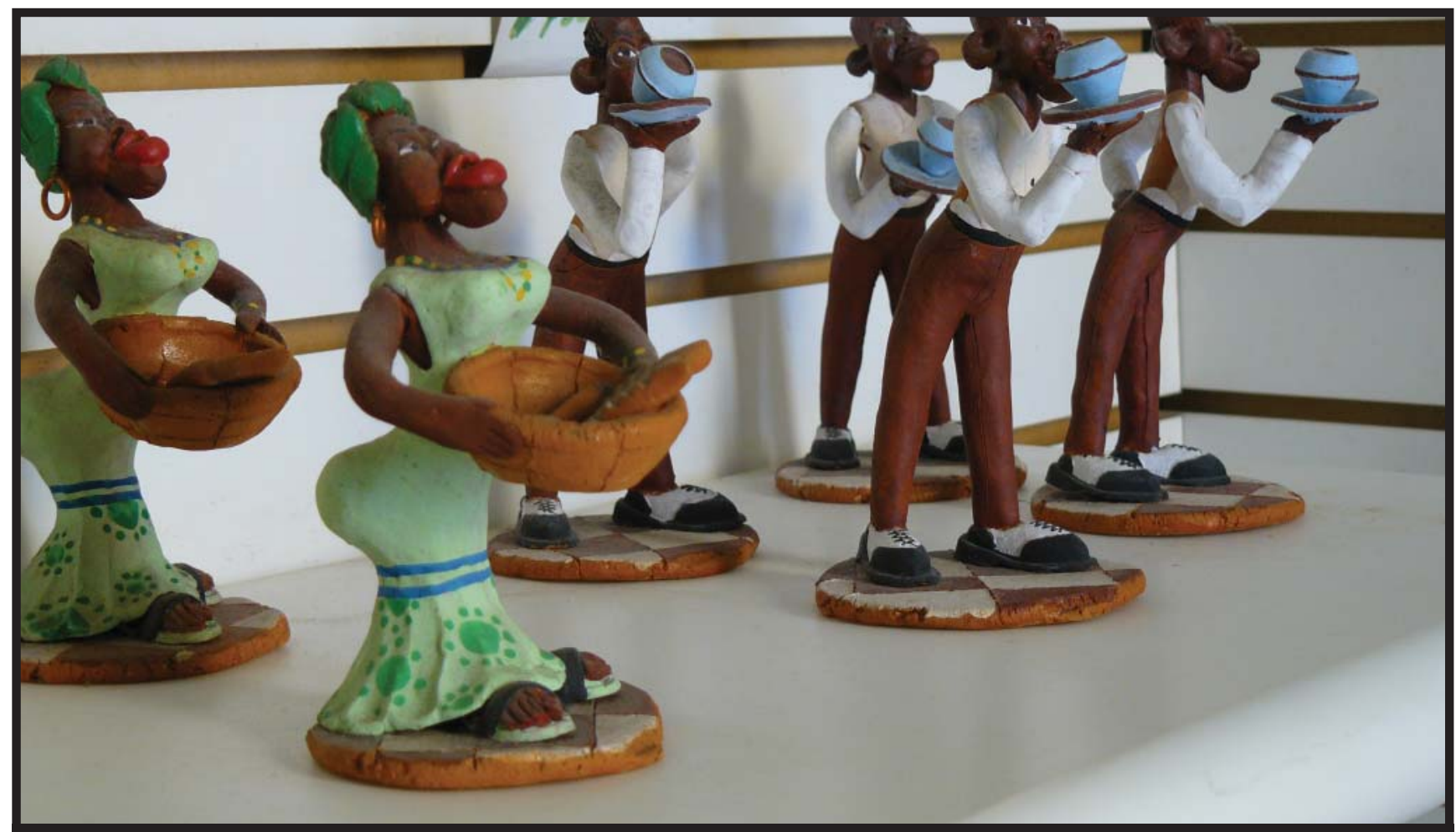

Figure 3: Gift shop, Museo Historico de Guanabacoa 
flowers or fruits and bright smiles. Where the older women are stationary, planted in their spots, the younger women are mobile, approaching tourists as they are disgorged from buses or simply wandering on foot through the historic district, offering to pose for photographs for a small fee. The somewhat more abject or rebellious figures of the male slaves, usually in small ceramic figures or wooden carvings, do not have real-life counterparts outside of staged folkloric performances, many of which include a choreographed set piece of a slave revolt, but the carved and painted waiters and musicians come to life in tourist spots across the country. Hundreds of professional musicians - a majority of whom, for historic reasons, are Black men, all of whom are State employees - regale patrons at indoor and open-air bars, cafes and restaurants, while other men (and some women) many of whom are Black - prepare and serve the food and drink that the patrons consume. ${ }^{46}$

While a full analysis of each of these iconic images and performances would be an intriguing and useful exercise, it is beyond the scope of this article. However, it is worth delving into one common figure, the dark-skinned female cloth doll who looks like a Cuban counterpart to the "Aunt Jemima" or "mammy" dolls in the U.S., and who has a complicated legacy in Cuban popular culture. ${ }^{47}$ The stout, dark-skinned woman wearing a head wrap was a popular image in nineteenth century marquillas, which are a rich source for studying racial and gender ideologies in colonial Cuba. Well-known fine artists such as Victor Landaluze created designs for many of the labels, and they blur the boundaries between high art and commercial culture. Although Jill Lane argues that Blackface minstrelsy was sometimes used for anti-colonial ends, the visual narratives in the marquillas often played out racialized fears about Cuba's future and specifically the place of Blacks..$^{8}$ The dark-skinned woman or negra in the tobacco marquillas is often the mother of the light-skinned mulata, who is depicted as alluring and highly desirable. She reflects a national racial/gender ideal. While the negra is thus implicitly or overtly the sexual partner of a White man, she is never his wife, and the visual portrayal of their relationship sometimes suggests rape or seduction on the one hand, or a commercial transaction on the other. While the dark-skinned woman is thus shown as a sexual being (unlike some of the more desexualized portrayals of dark-skinned Black women in U.S. popular cultural iconography), she is clearly less desirable than, and inferior to, her lighter-skinned offspring. ${ }^{49}$

However, turning an ethnographic lens on how the dolls in circulation today are consumed, we find that not all are purchased by tourists. I saw numerous dark-skinned female dolls with head wraps -- sometimes older, visibly careworn, and with less exaggerated features -- in the homes of Cuban friends. In some cases they were simply decorative items, placed on crocheted doilies on a sofa or shelf, but often they were part of an altar for one of the African-origin religions. In these contexts a doll may personify a person's spirit guide in espiritismo (spiritism), one of the orishas in la regla de ocha or santeria (the deities Yemayá and Oyá are both represented as dark-skinned Black women), or a similarly powerful female figure in Palo Monte. The dolls serve as entry points for the divine healing energies of these religious practices, and are thus sacred items. When I photographed my friend Caridad Moré, she chose to sit in front of her altar with one of her dolls in her arms (see Figure 4).

As material cultural artifacts associated with African-origin religions, older dolls which are no longer used for religious purposes have passed into the collections of museums with ethnographic displays devoted to these religions such as the Historical Museum of Guanabacoa or Casa de Africa, becoming "objects of ethnography." $5^{\circ}$ Their real-life counterparts are not limited to the self-exoticizing fortune tellers of Habana Vieja, but can be found in religious ceremonies, markets and households across the island.

Aside from a few scholars and artists, few Cubans (including Black Cubans) seemed troubled by these images. They have become naturalized as part of the island's visual iconography and abound in local domestic material culture. An African American female scholar reported questioning some vendors in old Havana (while trying to conceal her own troubled response to the images). She noted that they 
seemed genuinely proud of the items, and thought them beautiful and important representations of authentic Cubanness with no trace of irony. ${ }^{51}$

Alexis Esquivel, a Cuban artist whose work critically interrogates race, has produced a series of paintings and performances based on these dolls. He noted that many Cuban viewers do not "get" the critical component of his work but instead view the paintings as high-end, slightly abstracted versions of the kitschy popular culture items. To underscore how much these stereotyped images have become normalized and taken for granted, he added that since he purchases dolls as models for paintings or to include in performances, once he has finished using the dolls, his mother asks for them afterwards to decorate her apartment. ${ }^{52}$

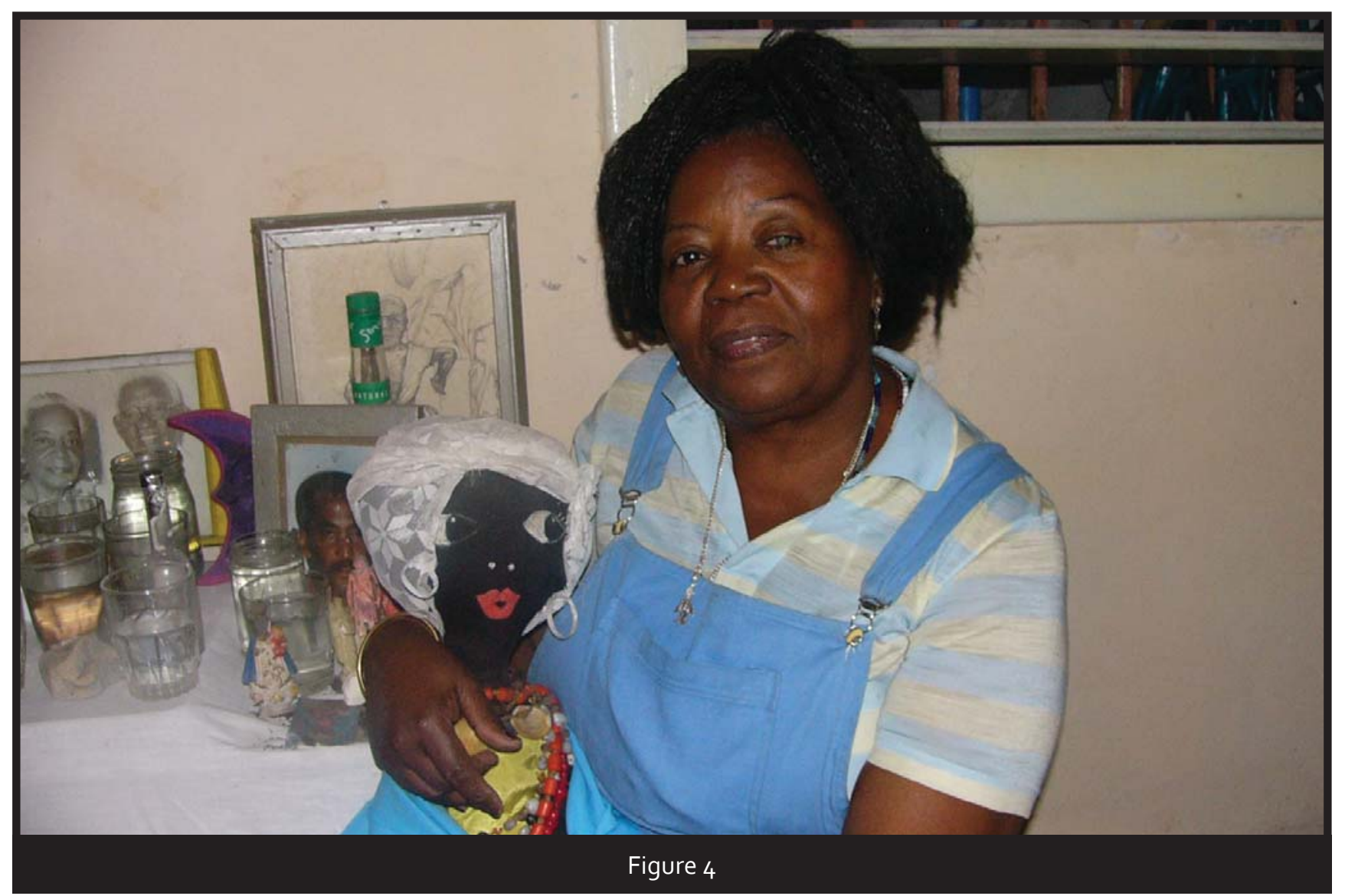

\section{Performing the nation}

I now turn to a fully theatricalized performance drawing upon Afrocuban religious music and imagery. For the last decade or so, on January 6 at around mid-day, a festive, noisy and colorful parade has snaked its way around the streets of Habana Vieja. Led by a regally-attired couple, the King and Queen of the parade (see figure 5), the event labeled "La Salida de los Cabildos" is sponsored by Casa de Africa (Africa House), a museum that houses a substantial part of the collection of Fernando Ortíz, often heralded in scholarly and bureaucratic discourse as "the third discoverer of Cuba" for his efforts to document and legitimate African-derived religious and musical practices as authentic and essential components of the ajiaco or "stew" of Cuban national cultural identity. 53 And the date of this procession - January 6 - was not randomly chosen. The procession purports to be a recreation of the Día de los Reyes (literally, "day of the kings" but usually translated into English as Three Kings' Day), the Feast of the Epiphany on the Catholic calendar. During Spanish rule this was the only day when Havana's substantial population of Africans and their descendants - both free and enslaved - were permitted to "go out" (salir) onto the city streets with drums and costumes and "perform themselves". 
The exact itinerary of the recreated parade varies from year to year, as the parade organizers must factor in the State of reconstruction and preservation efforts, and both performers and the ambulatory audience must work their way around scaffolding, wooden beams and potholes. However, unlike the quotidian and more informal cultural performances described above, the modern-day parade was designed as a somewhat more high-minded endeavor and attempts to provide an "authentic" representation of the African contributions to Cuban culture. At each of the central plazas, the procession stops and performers present a short set piece of music and dance from one of the sacred Afrocuban traditions: the regla de ocha or santeria (derived from the Yoruba-speaking peoples of what is now Nigeria), Palo Monte (based on Bantu or Congo cultures of West-Central Africa), and the masked dancers, called iremes or diablitos ("little devils") of the all-male Abakuá secret society (based upon similar sodalities in the Calabar region of what is now Nigeria). However, for the passing tourist, there is little to distinguish this once-a-year parade from the everyday, more overtly commoditized spectacles that I have just described; there is no emcee or explanatory brochure.

The event of which it is a somewhat aestheticized and fanciful reinterpretation, the Díia de los Reyes, is part of the complex and doubly bifurcated carnival tradition in Cuba. ${ }^{54}$ The modern-day event, the Salida de los Cabildos, takes its name from the one form of socio-cultural organization that Blacks were permitted during the tiempo de la colonia (colonial times) - the mutual aid societies called cabildos. The cabildos, originally established under the auspices of the Catholic Church, were relatively autonomous and established their own internal social organization. They were often able to purchase buildings and land (as well as the freedom of their enslaved members), and since the authorities often left them alone, they provided a fertile ground for the preservation or recreation of African religious and cultural practices. ${ }^{55}$

During the colonial period, Havana, like many other cities in the circumCaribbean, had Black and White carnivals that were separated spatially and temporally. The Creole (island-born) elite held a pre-Lenten Carnival rooted in medieval European traditions. Blacks were only allowed to participate in the White carnival in a limited way and were to organize their own comparsas (street bands).

However, Blacks were allowed to parade in the streets with costumes and comparsas on January 6 . While Blacks reveled in the streets and plazas, Whites watched from the safety of their balconies. The streets of the old city, on that day, were a Black space. The closest we have to an ethnographic or historical record of these events are a few verbal and

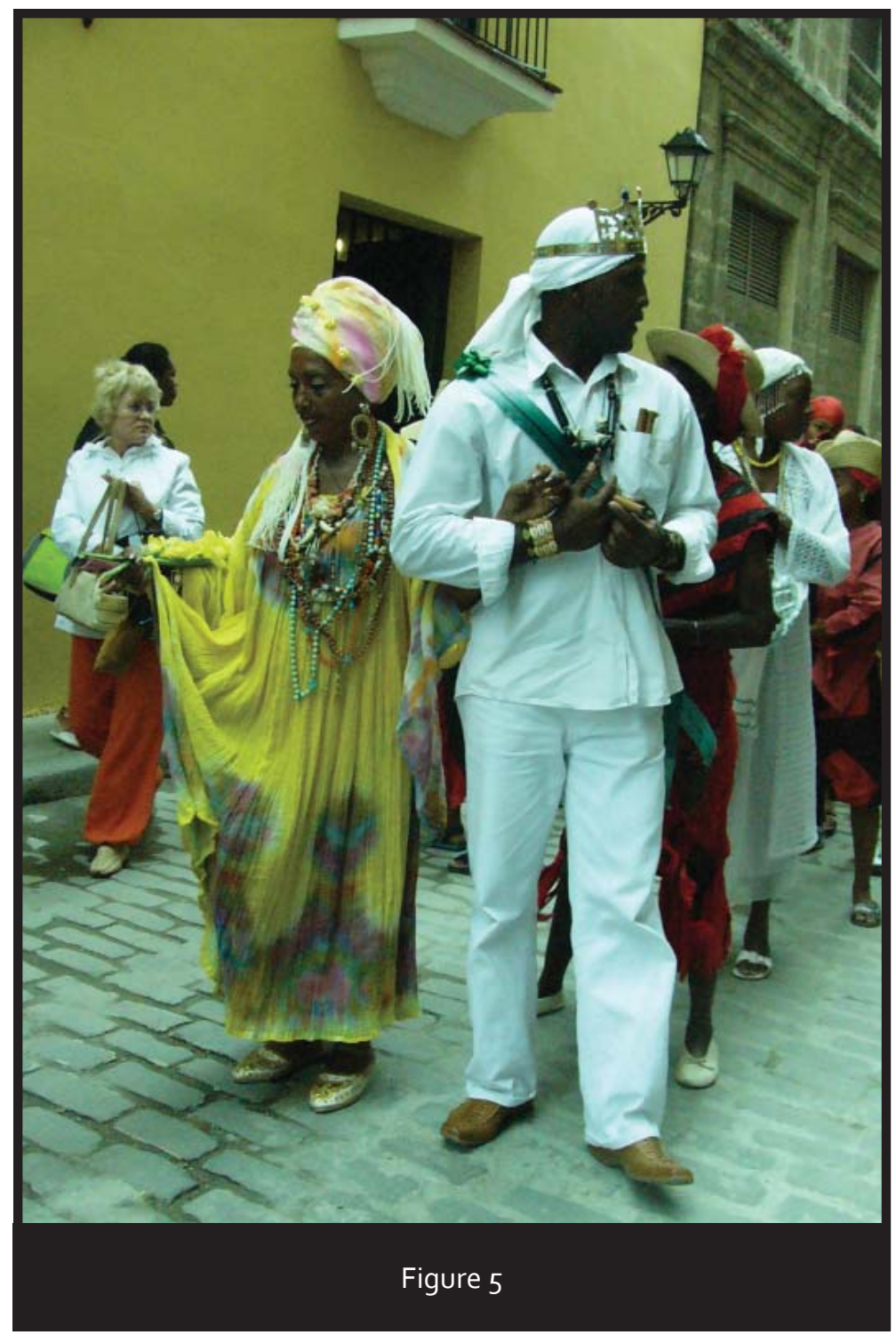


visual sketches, mostly from European visitors, and some police records. According to these accounts, the Día de los Reyes was exuberant, festive and noisy.

The Día de los Reyes, like other forms of Black cultural production, especially those involving drums and disorder (real or imagined), was subject to disciplining and repression by the colonial authorities. During Cuba's protracted wars of independence (starting in the 1860s), colonial officials and the elite feared that Blacks might join the anti-colonial struggle or revolt on their own. The authorities closed down many cabildos, and the Día de los Reyes was restricted and eventually banned in the mid1880s. ${ }^{57}$ According to older Habaneros (Havana residents), people continued to celebrate the Día de los Reyes but in smaller, more private ways. ${ }^{8}$

Most of the actual cabildos, the mutual aid societies that historically served enslaved and free Blacks, no longer exist today. Some of those that were closed by colonial authorities were later allowed to reopen. However, Black culture again became a flashpoint for racial fears after Cuban independence in the early twentieth century. Many Blacks had fought in the liberation army as they saw independence as the way to end slavery, and perhaps achieve Marti's vision of a raceless society. However, their hopes for full inclusion were not realized, and some Black veterans formed the Partido Independiente de Color (the Independent Party of Color) in 1908. The authorities reacted by outlawing parties based on race or class. The PIC led demonstrations in Oriente Province that the press immediately labeled a race war or an armed revolt. The government response was bloody and brutal: several thousand Blacks (not all of them supporters of the PIC) were killed by soldiers dispatched to "put down" the revolt. Newspapers carried wild reports about Blacks murdering and raping Whites, and civilian militias killed dozens of people throughout the island who had nothing to do with the protests. ${ }^{59}$

In this climate, the modernizing elite launched efforts to wipe out what they saw as backward, savage and atavistic elements of Cuban culture. A wave of "witchcraft" scares swept the country and Afrocuban religious practitioners were harassed and arrested. Several abductions and murders of White children were attributed to Black "sorcerers". The police harassed and sometimes arrested Afrocuban religious practitioners, broke up ceremonies and seized religious objects. The cabildos that managed to survive until the triumph of the Cuban revolution in 1959 ironically fell victim to the new government's proscription of race-based organizations. Since the revolution had abolished racial discrimination, the argument went, historically Black organizations were at best an anachronism and unnecessary, and at worst, divisive and racist. Thus most of the remaining cabildos were closed. ${ }^{60}$

The history of Carnival follows a similarly bumpy course. During the final war of independence, the colonial government pre-Lenten Carnival (the "White" carnival) was also suspended, but was reinstated by the U.S. occupation government. Blacks demanded the right to participate and eventually were granted a place, and by the early twentieth century the pre-Lenten Carnival combined elements of Black and White traditions: White beauty queens on floats (usually with corporate or political sponsors) surrounded by Black comparsas. The comparsas, which have been severely under-studied, were highly localized, based in the historically Black and working class barrios marginales (marginal neighborhoods) of Havana, and to this day, the competition between them reflects longstanding place-based identities and rivalries. ${ }^{61}$ During the political and economic turmoil of the 19305 and 405 competing political factions often turned Carnival into a political arena, and many popular carnival songs (some of which are still sung today) contained subtle (or not so subtle) political critique or even campaign slogans.

While much of the nationalist elite saw Black culture as anachronistic and atavistic, in the 1920 a section of the Cuban intelligentsia turned to Afrocuban culture as an authentic source of national cultural identity free of foreign influences. ${ }^{62}$ Pioneering ethnographers like Fernando Ortiz, Róomulo Lachatañeré and Lydia Cabrera painstakingly documented Afrocuban cultural and religious practices. ${ }^{63}$ 
Ortiz used his research to lobby for the reinstatement of the Black comparsas in Carnival. ${ }^{64}$

As was true elsewhere in the Caribbean, unstable or dictatorial governments often feared that boisterous public cultural expressions like Carnival, that brought masses of people into the streets, would give way to something more seriously threatening, and in the 1950 s the dictator Fulgencio Batista again banned Carnival. The cultural fervor of the early years of the Cuban revolution included efforts to revive (as well as document) "authentic" popular cultural traditions like Carnival, while infusing them with socialist values. Fidel Castro proclaimed Cuba an "Afro Latin" nation and Africanbased cultural practices and religions were revalorized as national patrimony (although as culture and not as religion). In the early 1960 s the comandantes (commanders) paraded in what was billed as "Santiago-style" Carnival; a much-quoted aphorism from Che Guevara describes Cuba's as a "revolution with pachanga"(or "swing").

As part of the effort to inscribe Carnival into the revolutionary project, during the campaign for the ten million ton sugarcane harvest in the 1970s, the authorities shifted Carnival from February to July so as not to interfere with the sugar harvest. During the severe economic crisis in the early 1990 s that followed the collapse of the Soviet Union, the government cancelled Carnival, and then reinstated it in $1995 .{ }^{65}$ By the late 1990 s, as part of the government's efforts to package Cuban culture for touristic consumption, Carnival was made more "commercial". Traditional neighborhood-based comparsas alternate with floats bearing dancers from the re-opened Tropicana and other cabarets. Although these cabarets are all owned by the State, the floats resemble those from the pre-revolutionary carnival. All along the Malecón, the seafront drive along which the parade proceeds, there are now food and beverage kiosks that are open for much of summer, and several relatively new cabarets and discotheques (in hard currency) where people can go for live entertainment after the Carnival parades.

Carnival is actually not a single event but a series of parades and competitions (with panels of judges appointed by the Ministry of Culture) that take place throughout the country over a period of several weeks. Each municipality is given a specific date for its local Carnival, with the festivities in Havana (which usually extend over two or three weekends) as the culmination.

Although Carnival is promoted as something that belongs to all Cubans, it is hard to avoid the conclusion that it is, in fact, largely a "Black" thing. Based on my observations of Havana's Carnival over several years, nearly all of the comparsa performers are Black, and Blacks are somewhat overrepresented in the boisterous crowds that line the Malecón to watch the parade. Like many Black-identified cultural and musical forms, including popular musics like timba and reggaetón, many Cubans associate Carnival (and the street) with rowdiness, excessive consumption of alcohol, and the Cuban equivalent of "slackness", and it is subject to intense policing. ${ }^{66}$

The revival of Carnival and the "invention" of the Salida de los Cabildos, although directed at somewhat different audiences, are both part of the But this Afrocuban "revival" did not begin after the collapse of the Soviet bloc but has its roots in the 1980s. In 1986, the government established Casa de Africa, a combination museum and research center, to further the work of Fernando Ortiz (and house some of the artifacts he had collected). In that same year, dockworker Francisco Moya (popularly known as "Pancho Quinto") and some of his co-workers formed an "amateur" folkloric group called Yoruba Andabo, significant in that it revived the use of wooden boxes (cajones), a percussion instrument that had fallen out of use in the 1940s. Yoruba Andabo, which eventually gained "professional" status, set the stage for the folkloric "boom" of the 1990s.

The push to develop international tourism (which included a vast historical restoration effort in Old Havana) thus overlapped with a modest renewal of scholarship on Afrocuban culture and, cautiously, 
on race more generally. ${ }^{67} \quad$ A scholarly symposium on Afrocuban culture produced the proposal to revive the Día de los Reyes celebration for Casa de Africa's tenth anniversary in 1996. Using a germinal essay by Fernando Ortiz as a guide, the museum professionals planned a parade and mapped out a route, and contracted folkloric performers to enact the parade. ${ }^{68}$ In several conversations and interviews, the professional staff reiterated a concern with authenticity and cultural preservation, and continually invoked Ortíz as a guiding and legitimizing force. ${ }^{69}$ However, it is almost certain that he never witnessed a Día de los Reyes parade himself: he was born in 1881, and thus would have only been a few years old when the event was banned by the Spanish authorities around 1884. Although when Ortíz wrote his essay in 1920 s he would have been able to find informants who had witnessed or participated in the previous century's celebrations, it does not appear that he sought any out; his descriptions of the processions are drawn largely from published accounts by costumbrista writers, and nineteenth-century European visitors to Havana.

In their efforts to faithfully recreate a nineteenth century event, the heritage professionals also looked at work by artists of that era such as Landaluze - the same sources consulted by Ortíz. Ironically, then, the colonialist gaze became a guide to cultural authenticity in the present. In particular, they drew upon a well-known lithograph by Landaluze, "El Día de los Reyes", that depicts an open-air plaza in Habana Vieja as a scene of carnivalistic excess. In this widely-reproduced print, as costumed and masked dancers whirl, a Black man with an open shirt collar vigorously pounds a drum, while another lifts his arms skyward in abandon. ${ }^{70}$

At the same time, the museum staff understood that the procession had to "play" to contemporary audiences. The event's dramatization draws upon the established conventions of State-sponsored folkloric spectacles. It is selective and representative. The seeming spontaneity is highlychoreographed so that the parade hits numerous plazas to catch as many different groups of tourists as possible as they sit in cafes or make their way to other sights and spectacles.

But the presentation also relies upon embodied knowledge of folkloric performers; these "culture bearers" have different performative criteria and many have their own agendas. ${ }^{71}$ The artistic director, Daniel Rodriguez, is a religious practitioner whose professional career as a folkloric performer extends back to the early years of the Revolution. He views this as an opportunity to "open a space" for Black public cultural production and to encourage a lot of young people to learn traditional music and dance. Many of the performers are children and teenagers whom he has taught, and he sees their participation in the Salida de los Cabildos as crucial to ensuring that this embodied knowledge gets transmitted to new generations and remains vital..$^{72}$

There is thus some tension and confusion about who controls the spectacle, the museum professionals or the performers. In 2005, I witnessed one open clash when Natasha, the parade director, decided that the performance by Ojun D'gara, a group of folkloric performers who had made a several hour bus journey from a rural town in Matanzas province, was dragging. Natasha is a White professional whose knowledge of Afrocuban culture came primarily through courses she received as part of her job. With no warning, she abruptly signaled another group to start playing in the middle of a song by Ojun D'gara, in order to "move things along." The Matanzas performers stopped, confused, and let the other group continue. Natasha later told me that she had intended to ask Ojun D'gara to play again at another point in the parade, but she did not get a chance. The performers were offended by the way they had been treated, but did not openly challenge Natasha, as they were, after all, State employees and this performance was part of their monthly "quota". However, they decided that they had completed their contractual obligations and quietly packed up their instruments, and walked back to their bus. I chatted briefly with them, along with some of their Havana-based friends and relatives who had turned out to see them perform. Then they boarded the bus without much fanfare and headed back to Matanzas while the parade continued. ${ }^{73}$ 
Events like the Salida de los Cabildos evoke contradictory reactions from Havana residents and those most concerned with Afrocuban cultural production. Some folkloric performers and cultural observers I knew dismissed the event as a show for tourists. However, many of the performers, as well as some community residents, see it in a positive light, as a means of reclaiming and preserving cultural traditions that might otherwise be forgotten or marginalized. Daniel Rodriguez, the musical director, explained to me that he had made a conscious choice to "take advantage" (his term) of the opportunity. It is also, quite literally, temporary reclamation of an increasingly privatized public sphere, as more and more of Old Havana (and other World Heritage sites like Trinidad) is turned over to tourist-friendly enterprises and local residents often feel that their neighborhoods and cities no longer belong to them. Historic restorations have often been carried out with an eye towards tourists rather than the needs of local residents. The majestic plazas are lined with restaurants, cafes and stores that are beyond the means of most Cubans (although the upper floors of many of the buildings still contain residential apartments), and metal bollards help define and discipline the space..$^{75}$ Several friends noted with some irony that while the centerpiece of the restoration of Plaza Vieja was a lavish water fountain, it was surrounded by a wrought-iron fence.

Black cultural performances in public spaces - even when sponsored by State cultural institutions still evoke anxiety and racialized fears of social disorder. ${ }^{76}$ Events that draw large crowds - such as the revived Carnival celebrations - are constructed as unruly and heavily policed. These attitudes are widely shared by many Cubans. Many of my Cuban friends disdainfully proclaimed that they never attended the Carnival parade on the Malecón because it was too noisy, rowdy and dangerous, and preferred to watch it on TV. They treated my interest in observing it firsthand as one of those idiosyncratic notions that foreigners are prone to, and reminded me to be on my guard. ${ }^{77}$ Black male bodies are treated as especially problematic. On two occasions, Black male friends who had accompanied me to the Carnival parade ended up spending a night in police custody because they were not able to produce a carnet de identidad (national identity card) when stopped by the police. ${ }^{78}$

Open-air sites where rumba and other folkloric music/dance genres are performed usually have a visible police presence and the organizers often strive to ensure that performances start and stop on time and do not turn into all-day or all-night jam sessions. ${ }^{79}$ Although the Salida de los Cabildos is usually held on a weekday afternoon and draws relatively small crowds it is not completely controllable and often threatens to overspill its bounds. The parade is popular with local residents and Cubans who work in some of the numerous unglamorous jobs in the Centro Historico. As the procession passes, Cuban workers and residents lean out of their windows, spill onto the sidewalks, or take an impromptu break and join the procession in their work uniforms. (See Figure 7). The heritage professionals at Casa de Africa commented that in staging the parade, they had to be concerned about the crowd behavior since bystanders sometimes got too enthusiastic, and they were worried that if they did not keep the parade moving, it would turn into a free-for-all. ${ }^{80}$

Taken together, the parade and the dolls can help us understand some of the complex intertwinings of the ethnographic and the carnivalistic in contemporary Cuba. An ethnographic approach to the carnivalistic in Cuba would necessitate, of course, analyzing the perspectives and agendas of the various social actors engaged in the production and consumption of each of these performances or items, and the multiple contexts implied or involves. For example, it would be fascinating to more fully analyze the figurines and other souvenirs, and the cultural and political economiesy of their production and circulation. Similar items are sold in a variety of locales: at hard currency shops located in tourist areas, in hotel lobbies and museums, at open-air markets known as ferias, but also at hard currency shops in ordinary neighborhoods where few tourists go. In the case of the ferias, especially those outside of Havana, sometimes the artisans themselves are vendors, but most frequently the vendors are not the producers, so it would be interesting to know something more about how the 
artifacts are producedtheir production, and how the designs and styles are selected (whether by individual artisans working independently, through design codes or production quotas established by the Ministry of Culture or other government bodies, or a combination).

Likewise, there is need for more in-depth ethnographic research on folkloric performance in "late socialist" Cuba, and the life-world of folkloric performers in the special period and beyond. The few book-length studies that have been written to date are based on fieldwork conducted either prior to the special period or with émigré performers in the United States. ${ }^{81}$ How do individuals and ensembles navigate between commerce and cultural preservation, between the ritual sphere and the market?

My intention in leaving some rough edges and unanswered questions is to argue against intellectual maneuvers that artificially separate some of these productions as authentic (and thus innocent) and demean others as cynically opportunistic.

The lines are much more blurred. As George Yúdice argues, grassroots social actors consciously make use of the same cultural symbols and performances that are promoted or presented by State institutions or non-governmental organizations for their own ends. ${ }^{82}$ The Cuban social actors I have described here may participate in several registers of cultural performance: many, if not most, of the performers who enact the staged Orisha dances in the Salida de los Cabildos are initiated priests and priestesses. ${ }^{83}$ Some are professional dancers or musicians who also perform in nightclubs and cabarets. The woman who enacts the role of a spiritualist or fortune teller in the Plaza may in fact be a respected healer in her community. The multiple agendas sometimes dovetail, overlap, intersect or clash. Tourist development and commoditized selferoticization may seem like reasonable - if remote - options to localized actors in the rural zones around Matanzas and Trinidad where most of the "Slave Routes" sites are located and where old slave quarters are still used as housing.

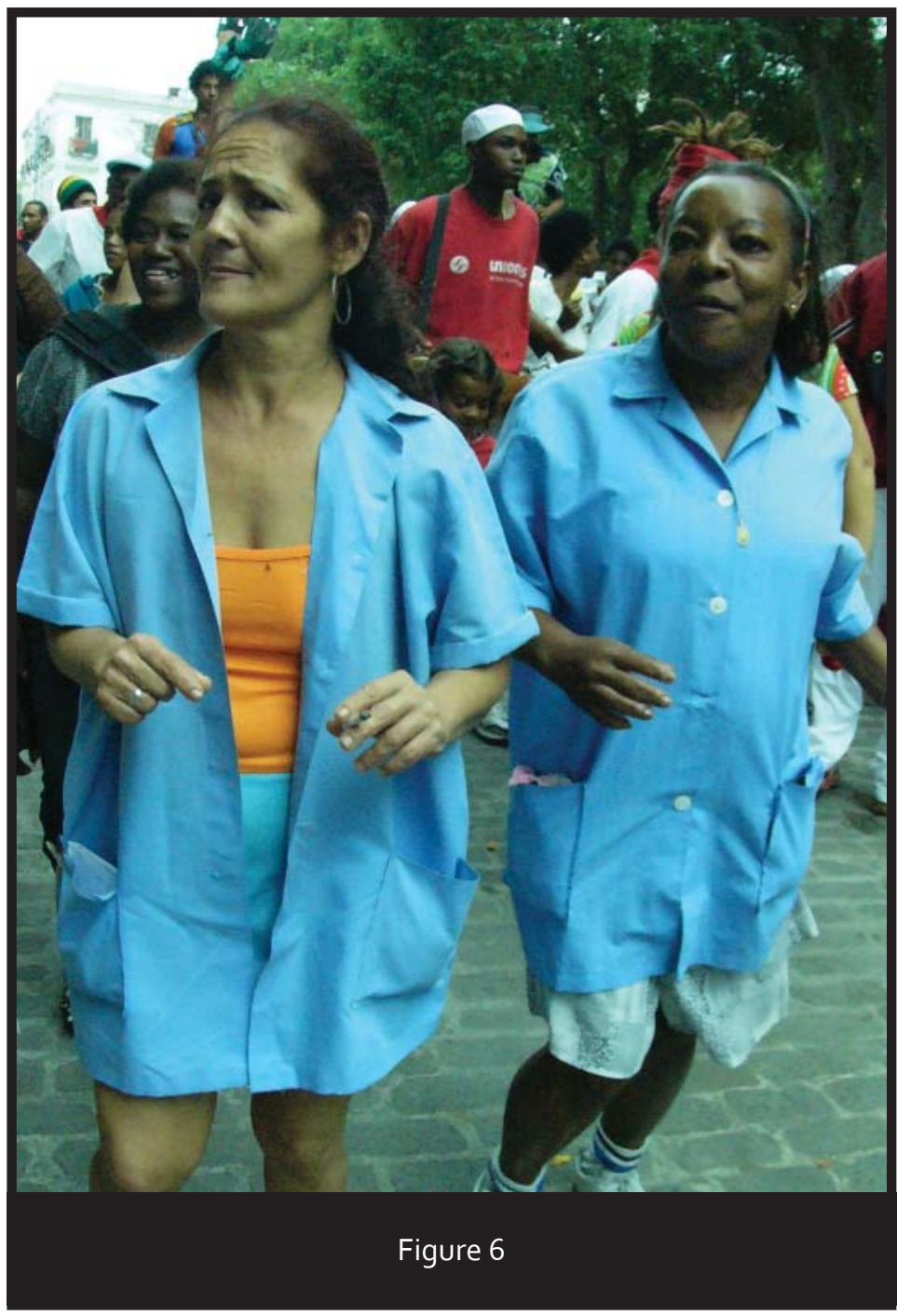
Residents in one community I visited in rural Matanzas province have repurposed slave-era relics, including some that are on the Office of Patrimony's registry; for example, the huge metal cauldrons used for boiling sugar cane juice are used as water tanks.

The un- or under-narratives nature of the ethnographic displays and spectacles may be unsettling, but it also allows me to make a different analytical point: that the scholarly text, the ethnographic display and the blatantly touristic commodity do not occupy completely separate realms but are closely interrelated registers through which slavery and its legacy are simultaneously silenced and consumed. I want to close with a comment made to me by Cuban historian Leyda Oquendo when 
I came to interview her for this project: she noted wryly that our own scholarship was part of the consumption. ${ }^{84}$

\section{References}

1. The present article draws upon papers I presented at the conference of the Association for the Study of the World African Diaspora (ASWAD) in Georgetown, Barbados, October 7-10, 2007, and the conference, Carnival: 'A People Art' and Taking Back the Streets, held at York University, Toronto, July 30 -August 3, 2008, and benefitted from the generous feedback of co-panelists and other participants. The analysis presented in this article has been sharpened by many conversations over the years with other students of race and Cuban culture, both in and out of Cuba, many of whom are cited in what follows. I am extraordinarily grateful to the two anonymous peer reviewers for Race and Ethnicity in a Changing World, who read the manuscript in record time and provided thoughtful and precise comments. They were models of what the peer review process should be. I was not able to fully utilize the many excellent suggestions they offered, but the article is much improved by my efforts to respond to them. Any deficiencies or weaknesses in the discussion are mine alone. I am also grateful to the editors of the journal for their unflagging enthusiasm and patience.

2. Trouillot, Michel R. Silencing the Past: Power and the Production of History. Boston: Beacon Press, 1995 p. 85

3. There is a growing body of scholarship about the problematic relationship between race and national identity during the last century and a half of Cuban history. Historian Ada Ferrer has argued that the status of Cuba's growing (mostly enslaved) black population vexed the nineteenth century independence movemen - see Ferrer, A. Insurgent Cuba: Race, Nation and Revolution, 1868-1898. Chapel Hill: University of North Carolina Press, 1999. See also Moore, R. Nationalizing Blackness: Afro-Cubanismo and Artistic Revolution in Havana, 1920-1940. Pittsburgh: University of Pittsburgh Press, 1997.; De la Fuente, A. A Nation for All: Race, Inequality, and Politics in Twentieth-Century Cuba. Chapel Hill: University of North Carolina Press, 2001., and Helg, A. Our Rightful Share: The Afro-Cuban Struggle for Equality. Chapel Hill: North Carolina Press, 1995.

4. The brochure distributed at the Museo Histórico de Guanabacoa is a case in point. The opening essay by Cuban scholar Marta Arjona extols the "immense aesthetic value" of the ceremonial objects, and expresses gratitude to "the children of Africa who have ... left upon our culture their indelible imprint." Marta Arjona, "Museum of Guanabacoa: A Wealth of Afrocuban Traditions." Introductory essay in Museum of Guanabacoa: A Wealth of Afro-Cuban Traditions (Museum catalog, Museo de Guanabacoa: Ciudad de la Habana, Cuba: no date), p. 9.

5. I use the term "cultural production" as a very broad rubric, encompassing material objects such as tourist souvenirs, as well museum exhibits and cultural performances.

6. Fernando Ortiz uses the terms "black carnival" and "white carnival" in his 1920 essay "La antigua fiesta del dia de los reyes," reprinted in Barnet, M. and Fernandez, A., eds. Ensayos Etnográficos Havana: Editorial de Ciencias Sociales, 1984, pp. 11-40.

7. Other discussions of the Cuban state's efforts to regulating cultural expression (including black identified cultural forms) are found in Perry, Marc. Consuming Blackness: Neoliberal Economies of Race in Late Socialist Cuba, unpublished manuscript., and Fernandes, S. Cuba Represent! Cuban Arts, State Power and the Making of New Revolutionary Cultures Durham, NC: Duke University Press, 2006., among others. More specific analyses of the state efforts to institutionalize "folklore" can be found in Vélez, Maria T. Drumming for the Gods: The Life and Times of Felipe Garcia Villamil. Philadelphia: Temple University Press, 2000., Hagedorn, K. Divine Utterances Washington, DC: Smithsonian Institution, 2001., and Hernandez-Reguant, A. Cuba's Alternative Geographies. Journal of Latin American Anthropology, 10(2), 2006, pp.275-313.

8. The concept of "encoding" is drawn from the work of cultural theorist Stuart Hall - Hall, S. Encoding/ decoding. In: Hall, S. Culture, Media, Language (1980) New York: Rutledge, pp.128-138. The concept of "cultural performance" was first articulated by anthropologist Milton Singer in 1955. For Singer, the term cultural performance encompasses both those activities usually defined as "cultural" (such as theater and music) but also festivals and rituals (including more private ones) that are usually categorized as "religion" or "ritual". See Singer, Milton The Cultural Pattern of Indian Civilization: A Preliminary Report of a Methodological Field Study. The Far Eastern Quarterly 15(1), 1955, pp. 23-36.

9. There is a large and growing bibliography of anthropological and other critiques of how cultural property 
(including artifacts, performance and sites) and cultural identities are shaped by tourism and other neoliberal approaches. A good starting point is Barbara Kirshenblatt-Gimblett's essay, "Objects of Ethnography" - see Kirshenblatt-Gimblett, B. Objects of Ethnography. In: Karp, I and Lavine, S. eds. Exhibiting Cultures: The Politics and Poetics of Museum Displays. Washington: Smithsonian Institution, 1998, pp. 386-443. Kirshenblatt-Gimblett further develops some of these arguments in her book Destination Culture: Tourism, Museums and Heritage - see Kirshenblatt-Gimblett, B. Destination Culture: Tourism, Museums and Heritage Berkeley: University of California Press, 1998. Other useful works include Brown, Michael F. Who Owns Native Culture?, Cambridge, MA: Harvard University Press, 2004. Audra Simpson's forthcoming work on the Kahenwake Mohawk and Jessica Cattelino's study of the Florida Seminole explore the neoliberal treatment of indigenous identities in North America. See Simpson, A. To the Reserve and Back Again: Kahnawake Mohawk Narratives of Self, Home and Nation. Durham : Duke University Press, forthcoming, and Cattelino, J. Casino Roots: The Cultural Production of TwentiethCentury Seminole Economic Development. In: Hosmer, B. and O'Neill, C., eds. Native Pathways: Economic Development and American Indian Culture in the Twentieth Century. Boulder: University of Colorado Press, 2004, pp. 66-90. As Quetzil Castañeda and other scholars have argued, anthropology (and especially archaeology) is often complicit in the touristic reprsentation and consumption of racialized identities. See, among other works, Castañeda, Q. In the Museum of Maya Culture: Touring Chichen Itza. Minneapolis: University of Minnesota Press, 1996.

10. In recent years, scholars both inside and outside Cuba have begun to challenge (and break) the official silences around race. A signal publication was the 1990 publication of Cuban scholar Tomas Fernandez Robaina's book El Negro en Cuba 1902-1958 - see Fernandez Roba, T. El Negro en Cuba 1902-1958. Havana: Edition de Ciencias Sociales. 1900. - but as the title makes clear, Robaina's analysis stops at the eve of the revolution. Since the mid-199os, several U.S.-based and other international scholars have explored racial dynamics after the 1959 revolution. Alejandro de la Fuente's A Nation For All (ref. 3_includes several chapters on post-revolutionary Cuba, and race is a central theme in Robin Moore's Music and Revolution: Cultural Change in Socialist Cuba - see Moore, R. Music and Revolution: Cultural Change in Socialist Cuba. Berkeley: University of California Press, 2006 - as does Nadine Fernandez's book Revolutionizing Romance: Interracial Couples in Contemporary Cuba - Fernandez, N. Revolutionizing Romance: Interracial Couples in Contemporary Cuba. New Brunswick, NJ: Rutgers University Press, 2010. See also, among other sources: De la Fuente, A. The New Afro-Cuban Cultural Movement and the Debate on Race in Contemporary Cuba. Journal of Latin American Studies. 40(November) 2008, pp.697-720; Fernández, N. The Changing Discourse of Race in Contemporary Cuba. Qualitative Studies in Education. 14(2), 2001, pp.117-132; and Hernández-Reguant, A. Cuba's Alternative Geographies (ref.7). Within Cuba, several researchers at the Centro de Antropología conducted a long-term study of race - the publications they have produced include Espina Prieto, R. and Rodriguez Ruiz, P. Raza y desigualdad en la Cuba actual (Race and inequality in Cuba today). Temas, 45(Jan-March), 2006, pp. 44-54. Roberto Zurbano, an essayist and vice-president of the National Union of Cuban Artists and Writers (UNEAC), has published several pieces on race, including Zurbano, R. El triángulo invisible del siglo XX cubano: raza, literatura y nación (the invisible triangle of the Cuban zoth century: race, literature and nation). Temas 46(AprilJune), 2006, pp. 111-123.

11. For background on Cuba's "touristic turn", and some of the social and cultural implications, see Schwartz, R. Pleasure Island: Tourism and Temptation in Cuba, Lincoln, Nebraska: University of Nebraska Press, 1997. Both Cuban government sources and external observers have tabulated the ups and downs of Cuba's tourist sector over the past decade, with foreign (especially U.S.-based) sources often making dire predictions based on periodic downturns. Over the 1990 s tourism grew to around 2 million visitors annually, with tourism revenues accounting for a substantial share of the national economy.

12. There was a noticeable slump in international tourism overall and tourism to Cuba in particular following the September 11, 2001 attack on the World Trade Center but tourism appears to have recovered somewhat. According to Cuban government sources, there were 2.3 million visitors in 2008 - see: Grogg, P. Big Hopes for Tourism Industry. [Online] 2009 (Retrieved July 12, 2009) Interpress Service (IPS) Url http: http://ipsnews.net/news. asp?idnews $=46218$

13. The Cuban government had established farmers' markets in the early 1980 s but they were closed after a few years.

14. See Henken, T. Condemned to Informality: Cuba's Experiments with Self-employment During the Special Period, Ph.D. dissertation, Stone Center, for Latin American Studies, Tulane University; Sacchetti, E. Experimenting with Change: An Anthropological Perspective on Cuban Micro-Enterprise. Cuba In 
Transition. 16, 2008, pp. 301-315.

15. Pérez-López, Jorge F. Cuba's Second Economy. New Brunswick, NJ: Transaction Books, 1995.

16. See Gordy, K. Sales+Economy+Efficiency=Revolution? Dollarization, Consumer Capitalism and and Popular Responses in Special Period Cuba. Public Culture, 18(2), 2006, pp. 383-412.

17. I use the term "hard currency stores" throughout, although this label is not used in Cuba. Cuba currently has two official currencies: pesos cubanos ("Cuban pesos", also called moneda nacional, "national money") and pesos convertibles ("convertible pesos") that can be used at hard currency stores. Prior to the special period, ordinary Cubans were only allowed to use moneda nacional, and diplomats and party officials were able to use U.S. dollars at highly restricted hard-currency stores that were popularly called diplo-tiendas. After the Cuban government legalized the possession of U.S. dollars by ordinary citizens in 1993, the stores were colloquially called "dollar stores" and although ordinary Cubans were allowed to enter, few had the means to make purchase. In 2004, in retaliation for the Bush Administration's tightening sanctions against Cuba, the Cuban government declared U.S. dollars would no longer be accepted in retail stores, and switched to a currency called the peso convertible (abbreviated as CUC) that had been introduced in a limited way a few years earlier. The name is extremely ironic as this currency is not accepted anywhere outside of Cuba. U.S. dollars, Euros and other foreign currencies can be exchanged for CUCs or moneda nacional at currency exchanges and banks but the government levies an additional $20 \%$ fee on U.S. dollars.

18.

19. The passion for acquiring consumer goods was often satirized in Cuban popular culture. A highly gendered critique is found in the song "La Shopimaniaca" (the female shopping maniac) by Los Van Van (from their 1998 CD Te Pone La Cabeza Mala). The male narrator of the song exasperatedly but affectionately laments his girlfriend's endless purchases in dollar stores.

20. Espina Prieto, R. and Rodriguez Ruiz, P. Raza y desigualdad en la Cuba actual (Race and inequality in Cuba today). Temas, 45(Jan-March), 2006, pp. 44-54.

21. A discussion of sex tourism is beyond the scope of this article, but numerous scholars both in and outside of Cuba have noted the racialized contours of sex work in contemporary Cuba - for example, Lucia Cabezas, A. Discourses of Prostitution in Cuba. In: Kempadoo K. and Doezema, J. eds. Global Sex Workers: Rights, Resistance and Redefinition, New York: Routledge, 1998, pp. 79-86.; and Fusco, Hustling for Dollars: Jiniterismo in Cuba. In: Global Sex Workers: Rights, Resistance and Redefinition, New York: Routledge, 1998, pp. 151-166.

22. See Nadine Fernadez's critique of the Centro de Antropologia's study of race in Fernandez (ref.10). See also De La Fuente (ref. 3)

23. See, for example, Perry, M. Consuming Blackness (ref. 7) and Hernandez-Reguant, A. Multi-Cubanidad. In: Hernandez-Reguant, A. ed. Cuba in the Special Period: Culture and Ideology in the 199os. New York: Palgrave MacMillan, 2009, pp. 62-88.

24. See Hagedorn, K. Divine Utterances (ref. 7), Moore. R, Music and Revolution (ref.3)

25. State support or recognition of Afrocuban religious practitioners is not as developed in Cuba as it is in Salvador de Bahia, Brazil, where the Ministry of Culture has sponsored events honoring some of the most influential Candomble priestesses.

26. Cubans use a fluid and multi-tiered system of racial categorization in everyday speech. Terms like mulata and prieta (dark) are widely used, both as physical descriptors and terms of endearment that may not reflect a person's appearance. I am Euro-American, and yet Cuban friends will often greet me as "mi negra" (literally, "my black woman)". According to longtime observers, the Tropicana's performative aesthetics have not changed substantially in the fifty years since the Cuban revolution - including the extravagant and revealing costumes and choreography, and the selection of dancers by physical appearance: tall, long-legged and "mixed race" but light skinned. There are few if any dark-skinned blacks or whites. Although in the early twentieth century the Tropicana was run by the Mafia and associated with their drug and prostitution businesses, it escaped the fate of other nightclubs, most of which were closed shortly after the revolutionary government took power in 1959, because it was so popular with Cuban audiences. It was eventually closed in 1968 but reopened in 1970, and was heavily promoted when foreign tourists started arriving in large numbers in the 1990s. In 2003, the club's management announced that they were changing the show, replacing the music/dance revue "Tropicana: La Gloria Eres Tu" (Tropicana, the glory is you), in which the showgirls played a prominent role, with a show called "Tambores en Concierto" (drums in concert), focusing on the "roots" of Cuban rhythms. See Vanessa Arrington, "Havana's Tropicana switching rhythms, easing show of flesh." Associated Press, November 
2, 2004. Elizabeth Ruf Maldonado, who conducted research at the Tropicana in the early to mid 1990s, argues that the Tropicana's popularity with Cubans is due in part to the fact that the mulata embodies the national ideal of racial mixing or mestizaje and is thus a patriotic symbol, not only an object of desire. See MaldonRuf, E. Que linda es Cuba!: Issues of Gender, Color, and Nationalism in Cuba's Tropicana Nightclub Performance. TDR, 41(1), 1997, pp. 86-105. Kaifa Roland notes that female dancers tend to be "mulaticized" by headdresses and hairstyles that obscure their race. See Roland, K. Tourism and the Negrificacion of Cuban Identity. Transforming Anthropology, 14(2): 151-162, 2006 p. 158-9.

27. The correct terminology to describe African-origin or black-identified cultural practices in Cuba is the subject of some debate. The pioneering (and often problematic) scholar Fernando Ortiz used the term "Afrocuban religions," and other early twentieth century writers often referred to "Afrocuban cults". In recent years scholars and museum and heritage professionals have adopted the term, "religions of African origin" (although the word "cult" still appears from time to time). For a further discussion of this evolution, see Pedroso, Louis A. Las exposiciones de 'cultos afrocubanos' y la necesidad de su reconceptualización. Catauro: Revista Cubana De Antropología 3(5), pp. 126-141.

28. I use "festive ethnicity" here as a shorthand expression for the ways in which both state and non-state actors use performances, festivals, exhibitions and other visual and performative means to forge or reinforce ethnic, cultural, national, racial and other identities. The upbeat, celebratory tone of the narratives and performances effectively pre-empts or precludes any critical interrogation, and often serves the purpose of masking persistent inequalities with a veneer of harmonious inclusivity. In the hands of state institutions, festive ethnicity often undergirds specific nationalist projects, including official multiculturalism. On the other hand, ethnic and racial minorities can use festive ethnicity to challenge exclusionary practices and stake their own claims. There are many recent articles and a few books that provide nuanced analyses of these phenomena. David Guss' The Festive State: Race, Ethnicity and Nationalism as Cultural Performance examines festivals and performance in Venezuela - see Guss, D. The Festive State: Race, Ethnicity and Nationalism as Cultural Performance. Berkeley: University of California Press, 2000. Several of the chapters in Lisa Maya Knauer and Daniel Walkowitz, eds. Contested Histories in Public Space: Memory, Race and Nation explore these concerns in a variety of case studies see Maya Knauer, L. and Walkowitz, D. eds. Contested Histories in Public Space: Memory, Race and Nation. Duke University Press, 2009 - for example, Amar, P. Saving Rio's "Cradle of Samba": Outlaw Uprisings, Racial Tourism, and the Progressive State in Brazil. pp. 249-279; and Poole, D. Affective Distinctions: Race and Place in Oaxaca. pp. 197-227. See also Kuutma, K. Festival as communicative performance and celebration of ethnicity. Folklore: Electronic Journal of Folklore, 7, [online] pp. 79-86. 1998. (Retrieved July 12, 2009). (Url: http: www.ceeol.com.); and Steiner, C. The Invisible Face: Masks, Ethnicity and the State in Cote d'Ivoire. In: Roy Richard Grinker and Christopher Steiner (eds), Perspectives on Africa: A Reader In Culture, History and Representation. Oxford: Blackwell Press, 1997 pp. 671-679.

29. My translation. The original statement by Martí is "No hay odio de razas, porque no hay razas. .... Cubano es mas que blanco, mas que mulato, mas que negro..."

30. "La Vida es un Carnaval" (words and music by Victor Daniel). The song appears on at least two CDs by Delgado that were released in 2000: La Primera Noche (Caribe Productions), and La Formula (Ahi Nama Music). Delgado's music video of the song features hundreds of Cubans (mostly young women in skimpy clothing) gyrating and waving their arms as they sing and dance to the chorus. The song was also recorded by Celia Cruz, and numerous other performers.

31. Harvey, Daina C. (Re)Creating Culture Through Tourism: Black Heritage Space in New Jersey. In: Melanie Smith, Melanie K. ed. Tourism, Culture and Regeneration. Oxford: Oxford University Press, 2007. pp. 59-68.

32. Efforts to "preserve", renovate and/or restore urban sites such as New York City's Union Square Park have often been criticized for putting the interests of real estate developers and upper-middle class professionals over those of local residents. Aesthetic and design choices - reflecting elite visions and often enhancing the ability to secure and survey public spaces - have also come under critical scrutiny. See Deutsche, R. Evictions: Art and Spatial Politics. Cambridge: MIT Press, 1996.; Page M. and Mason, R. Giving Preservation a History: Histories of Historic Preservation in the United States. New York and London: Routledge, 2004; and Herzfeld, M. A Place in History: Social and Monumental Time in a Cretan Town. Princetown: Princetown University Place, 1991.

33. See Michael Herzfeld (ref. 32)

34. In Spanish, the Oficina del Historiador de la Ciudad de la Habana (OHCH).

35. For a more thorough discussion of the role of the $\mathrm{OHCH}$ in the reconstruction of Old Havana, and the powers of the agency, see Hill, M. Globalizing Havana: World Heritage and Urban Redevelopment in Late 
Socialist Cuba. Unpublished PhD dissertation, University of Chicago, 2004.

36. Lowenhaupt Tsing, A. In The Realm of the Diamond Queen. Princetown: Princetown University Press, 1993

37. The museum narrative contains its own gaps and silences. The Castillo remained in use as a prison until the 1980s, a fact that is not mentioned by the guides who take visitors to see the cells where slaves were kept. I am indebted to Julio Moracen Naranjo and Andres Reyes Rodriguez for supplementing my understanding of the site.

38. On the several occasions that I have taken one of the higher-priced air-conditioned buses that run between Havana and Varadero, I was one of the few people who disembarked at Matanzas.

39. Costumbrismo is a form of literary or visual representation that focuses on scenes of everyday life, or "local color". It is derived from the Spanish word for customs -- costumbres.

40. The manifold ironies of the marketing of Che have been dissected by numerous scholars, including Ariana Hernandez-Reguant - see Hernandez-Reguant, A. Copyrighting Che: Art and Authorship under Late Cuban Socialism. Public Culture 2004 16(1) pp. 1-30; Skoller, J. The Future's Past: Re-imaging the Cuban Revolution. Afterimage. 26. 1999

41. The complexities of museumized representations of Afrocuban religions are discussed by Luis Pedroso. Las exposiciones de 'cultos afrocubanos (ref. 27). A more detailed analysis of the ethnographic displays in the Museo de Guanabacoa can be found in Lisa Maya Knauer, "Afrocuban Religion in Cuban Museums" in Daniel Walkowitz and Lisa Maya Knaver, eds. Contesting History in Public Space (ref 28)

42. The imbrication of carnivalistic and ethnographic is not unique to Cuba: I purchased my Barbadian "Mammy" doll from the gift shop at the National Museum.

43. See Kutzinski, V. Sugar's Secrets: Race and the Erotics of Cuban Nationalism. Charlottesville: University Press of Virginia, 1993

44. I want to thank Tomas Fernandez Robaina for pointing me in the direction of the Landaluze paintings in the Museo de Bellas Artes.

45. In most of the African-derived religions practiced in Cuba, white represents purity, and participants in religious ceremonies often wear white or light colors. In la regla de ocha (santeria), new initiates (iyawos) dress exclusively in white for a year, and in both ocha and the Congo-derived practices colloquially referred to as palo monte or simply palo, initiates wear beaded necklaces that represent specific guardian spirits or divinities (called orishas in la regla de ocha and nkisi in palo). Cigars have many uses in religious contexts. Certain orishas, and eguns or muertos (spirits of the deceased) favor cigars, and participants in religious ceremonies frequently smoke cigars in an effort to attract those deities or spirits, or place cigars on their home altars. There are several reliable sources on Afrocuban religious practices and symbolism, including Mason, M. Living Santeria: Rituals and Experiences in an Afro-Cuban Religion. Washington, DC: Smithsonian Institution, 1992. and Ramos, M. The Lukumi Pantheon: The Orishas Worshipped by the Lukumi. [Online] (Retrieved on 8 July 2009] Url: http://ilarioba.tripod.com/articlesmine/Pantheon.htm.

46. Most of the staged performances of music and dance from the palo/Kongo traditions depict scenes of slaves being brutalized by their masters or overseers (as all the performers are black), and then banding together and using spiritual powers to vanquish their oppressors and liberate themselves. See Moore, R. (ref. 3) for a discussion of the role of black musicians in the nineteenth and twentieth centuries.

47. I have not found a widely-used Cuban name for these dolls. Some have suggested that the label "la negra Francisca" is often used.

48. Lane, J. Blackface Cuba, 1840-1895. Philadelphia: University of Pennsylvania Press, 2005. My reading of the marquillas draws upon Kutzinski's analysis, in Sugar's Secrets (ref. 43), and that of Alison Fraunhar - see Fraunhar, A. Marquillas cigarreras cubanas: Nation and Desire in the Nineteenth Century. Hispanic Research Journal. 9(5), 2008, pp. 458-478. For a fuller discussion of the "mammy" or "Aunt Jemima" image in U.S. popular culture and racial imaginings, see Turner, Patricia A. Ceramic Uncles \& Celluloid Mammies: Black Images and Their Influence on Culture. New York: Anchor Books, 1994.; and WallaceSaunders, K. Mammy: A Century of Race, Gender and Southern Memory. Ann Arbor: University of Michigan Press, 2006. An early treatment of the subject can be found in Dubin, Steven C. Symbolic Slavery: Black Representations in Popular Culture. Social Problems, 34(2) 1987, pp. 122-140.

49. One of the most explicit depictions of the racial and gender codes is a series entitled "The Birth of the Mulata", which begins with the sexual relationship between white man and black woman, and progresses through the "coming out" of the mulata as an alluring young woman. See Kutzinski, Sugar's Secrets, (ref. 3.)

50. See Kirshenblatt-Gimblett In: Karp, I and Lavine, S. eds. (ref. 9 pp. 386-443). According to the director of the Museo Histórico de Guanabacoa, many of the museum's early acquisitions of Afrocuban 
religious artifacts were donated by individuals who were not themselves religious but whose deceased relatives had been devotees - a result, perhaps, of the revolution's early avowedly atheistic stance and discouragement of religious practice (Grisel Fraga, interview with author, August 2005). Casa de África, on the other hand, acquired part of Fernando Ortiz' personal collection after his death. While Ortiz in his later years obtained religious items directly from his informants, his collection started with items that had been confiscated by the police when they broke up ceremonies. For a discussion of the contradictory nature of Ortiz's ethnographic work and in particular, his beginnings as a Lombrosian criminologist, see Bronfman, A. Measures of Equality: Social Science, Race and Citizenship in Cuba, 1902-1940. Durham: University of North Carolina Press, 2003. The Museo Montaner de Antropologia, housed in the Calixto Garcia Hospital, still houses a small collection of Afrocuban religious items that are a remnant of a "criminal ethnology" exhibit that dates back to the 1930s, when medical training included learning how to recognize potentially criminal behavior and individuals. The museum is only open by appointment, and is, according to hospital staff, still occasionally used for teaching purposes.

51. This account was related to me by an audience member at a panel where I presented an early version of this paper, at the conference of the Association for the Study of the World African Diaspora (ASWAD), in Barbados in October 2007. The speaker identified herself as African American but I unfortunately did not note her name.

52. Alexis Esquivel Bermudez, interview with author, June 2007. Esquivel was one of the first contemporary Cuban artists still residing in Cuba to offer critical perspectives on race in Cuba. In 1997, he curated a controversial and critically acclaimed exhibit entitled "Queloide I", ("keloid" is a medical term describing scar tissue; the show's title reference to the scars slaves bore as a result of whippings) followed by a show entitled "Ni Músicos Ni Deportistas" (neither musicians nor athletes). The Queloides shows (the most recent exhibit opened in April 2010) and Esquivel's own artwork are discussed in Fernandes, S. (ref. 7), and De la Fuente, A. (ref. 3).

53. Ortiz, F. Cuban Counterpoint: Tobacco and Sugar. Translated by Harriet Onis. Durham, NC: Duke University Press, 1995.

54. It is important to specify that this discussion primarily concerns Havana's carnival. Eastern Cuba, and particularly Santiago de Cuba, has a somewhat separate and distinctive carnival tradition marked by the region's proximity to Haiti, and other large cities have local carnivals. While Havana is the capital city and its carnival to a degree represents a "national" carnival, most Cuban scholars (and many ordinary citizens) consider Santiago's carnival to be more "authentic". The critique of Havana's carnival as too commercial dates back several decades, as noted by Robin Moore in the one chapter he devotes to comparsas and Carnival in the early zoth century. It is also reflected in the paucity of contemporary scholarship about Havana carnival by either Cuban or foreign writers. The chapter on Cuba in Judith Bettelheim's authoritative work on Caribbean festivals focuses exclusively on Santiago's Carnival. Another frame for exploring the dialectic of the ethnographic and the carnivalesque is thus the relationship between national and local. See Nunley J. and Bettelheim, J. Caribbean Festival Arts: Each and Every Bit of Difference. Seattle: University of Washington Press, 1988. Bettelheim also edited a relevant volume - see Bettelheim, J. Cuban Festivals: A Century of Afro-Cuban Culture. Princeton, NJ: Markus Wiener Publishers, 2001 - her own two essays in this volume also concentrate upon Santiago.

55. See Howard, Philip A. Changing History: Afro Cuban Cabildos and Societies of Color in the Nineteenth Century. Baton Rouge: Louisiana State University Press, 1998. His work builds upon Fannie Rushing's unpublished doctoral dissertation - Rushing, F. Cabildos de Nación, Sociedades de la Raza de Color: AfroCuban Participation in Slave Emancipation and Cuban Independence 1865-1895. University of Chicago, 1992. Both Howard and Rushing argue that the cabildos allowed blacks to both retain cultures and identities and forge new ones. George Brandon, in Santeria from Africa to the New World: The Dead Sell Memories - Brandon, G. Santeria from Africa to the New World: The Dead Sell Memories. Bloomington: Indiana University Press, 1997 - argues that it was in the urbanized setting of the cabildos that the modern religion known as santeria took shape, as free and enslaved blacks, often from different cultural backgrounds, pieced together African religion and spiritual practices under the nominal sponsorship of the Catholic Church.

56. See Ferrer, A. (ref. 3)

57. See Moore, R. (ref. 3)

58. Felix "Pupy" Insua, Cuban folkloric performer, personal communication, September 2005 (New York City); Juan Bencomo, master drum maker, personal communication, August 2005 (Havana, Cuba).

59. For further discussion of the PIC and the "war" of 1912, see (ref. 3). The PIC remains a controversial 
subject in Cuba, but some recent publications have begun to breach the long silence. Filmmaker Gloria Rolando's 2001 documentary Roots of My Heart was followed by Silvio Castro Fernandez's 2002 book, El Masacre de los Independientes de Color en 1912 - Castro Fernandez, S. El Masacre de los Independientes de Color en 1912. Havana: Editorial de Ciencias Sociales, 2002. This was the first substantial scholarly work published in Cuba focused entirely on the PIC, and it is notable that the title of the book, which carries the imprimatur a state-run publishing house, uses the word "massacre." In 2008, the centenary of the formation of the $\mathrm{PCl}$, the government allowed a plaque to be mounted on the door of the home occupied by founder Evaristo Evanoz in Habana Vieja.

6o. This is very similar to the role blacks were allowed to play in New Orleans' Mardi Gras.

61. Filmmaker Gloria Rolando's 2000 documentary El Alacrán (the scorpion), examines the history of Carnival and specifically one comparsa, El Alacrán, founded in 1908 and dedicated to the deity Yemayá.

62. See Moore, R. (ref. 3)

63. Starting in the late nineteenth century, most middle-class and educated Blacks sought to gain social acceptance by distancing themselves from these "backward" cultural practices. Rómulo Lachatañeré (1909-1952) was one of the first black Cuban intellectuals to write about Afrocuban religion. Both Ortiz and Cabrera were white; they were also brother and sister-in-law. Lachatañeré's first book, O mio Yemaya (published in 1938) was a path-breaking collection based on extensive oral history interviews with a santero (santeria priest). It was republished in English as Afro-Cuban Myths: Yemayá - Lachatañeré, R. Afro-Cuban Myths: Yemayá And Other Orishas. New York: Markus Weiner Publishers, 2006. Lachatañeré also wrote El sistema religioso de los afrocubanos - Lachatañeré, R., El sistema religioso de los afrocubanos. La Habana: Ciencias Sociales, 2001 [1942]; and Manual de Santería - Lachatañeré, R., Manual de Santería, La Habana: Editorial de Ciencias Sociales, 1995. Lydia Cabrera wrote over a dozen books on Afrocuban religions. Her first book, originally published in French in 1936 when she was studying in Paris, was Cuentos Negros de Cuba - Cabrera, L. Cuentos Negros de Cuba. Ediciones Universal, 1993 (1936). During the 1940 and 1950 s she conducted extensive fieldwork in Matanzas province, including supervising field recordings of religious music. She published two substantial volumes in Cuba, the massive 1954 work on santeria El Monte - Cabrera, L. El Monte. Ediciones Universal, 1995 (1954) and a linguistic study of ritual language Anagó: El Vocabulario Lukumí - Cabreara, L. Anagó: El Vocabulario Lukumí. Ediciones Universal, 1996. She left Cuba in 1959 and her remaining books were published in the United States. For a thorough assessment of Cabrera's scholarship and her legacy, see. Rodríguez-Mangual, Edna M. Lydia Cabrera and the Construction of an Afro Cuban Cultural Identity. Durham: University of North Carolina Press, 2004. Rodríguez-Mangual argues that Cabrera's work, which blurs narrative and ethnography, is not simply a continuation of Ortiz's efforts but marks an important shift in positioning Black Cubans as subjects and authors of their own narratives, and not simply objects of the (white) scholarly gaze.

64. See Moore, R. (ref. 3)

65. See Sanchez, R. Carnaval in Cuba, though less grandiose, remains a tradition. [Online] Url: http://www.sunsentinel.com/news/nationworld/sfl-flbcuba081osbaug10,0,1858314.story (South Florida Sun-Sentinel)

66. See Roland, K. (ref.26, pp 1-162).

67. In the 1980s, Cuban publishing houses began a modest revival of interest in Afrocuban themes and over a period of several years reprinted several volumes of Ortiz' work. At the same time, contemporary researchers like Natalia Bolivar, Tomas Fernandez Robaina, Lazara Menendez and others published books and articles on race and Afrocuban religion. For a fuller discussion of the Afrocuban "revival", see Hernandez-Reguant A. (ref. 23)

68. Ortiz, F. (ref. 6, pp. 41-78) - the essay was originally published in 1920 and republished several times during Ortiz' lifetime.

69. As noted earlier, Cuban scholars usually uncritically celebrate Ortiz for his "rescuing" of Afrocuban cultural practices. His training as a Lombrosian criminologist, is usually glossed over, treated as a "phase" or completely separate from his later conversion to Afrocubanismo, or ignored. For a critical appraisal of Ortiz's work and legacy, see Bronfman, A. Measures of Equality: Social Science, Citizenship and Race in Cuba, 1902-1940. Chapel Hill: University of North Carolina Press, 2004.

70. Interested readers can view the image online at INCOMPLETE!

71. The term portadores culturales, which literally translates as "culture bearers", is used widely by Cuban scholars, heritage and museum professionals, and occasionally by performers themselves.

72. Daniel Rodriguez, personal communication, January 2004, 2005 and interview by author, August 2006.

73. Professional musicians and musical groups belong to one of the state cultural enterprises (empresas) 
that fall under the aegis of the Ministry of Culture. The empresas are a cross between a state union, a professional guild, an management company and an employment agency. In theory, the empresa arranges performances and pays the musicians a monthly stipend based on a minimum quota of engagements, and arranges transportation, meals and accommodations when necessary. In practice, performers are often responsible for making their own arrangements.

74. An interesting comparison can be drawn with Pelourinho, in Salvador da Bahia, Brazil, also a UNESCO World Heritage site, which got its name from the whipping post (pillory, pelourinho in Portuguese) used for the public punishment of slaves. Pelo, as it is called by residents and tourist brochures alike, has continued to be home to a majority black (and poor) population. After Pelourinho received designation as "patrimony of humanity", many local residents were displaced for the "restoration" of historical buildings (some were simply bought out; others were temporarily rehoused and then allowed to return). Clarindo Silva, longtime resident and restaurant owner in Pelourinho, interview, June 1, 2009. See Collins, J. But What If I Should Need to Defecate In Your Neighborhood, Madame? Empire, Redemption, and the 'Tradition of the Oppressed' in a Brazilian World Heritage Site. Cultural Anthropology. 23(2), 2008 pp. 279-328

75. The bollards block off vehicular traffic, creating pedestrian zones, which are pleasing to tourists but not always favored by Havana residents, especially truck drivers, taxi drivers, and others whose livelihoods depend upon their maneuvering vehicles through Old Havana to deliver goods to stores or the nearby wharves. Tourists who take taxis to or through the historic district often find that getting from one point to another is a laborious process as many streets are blocked off.

76. See Fernandes, (ref. 7) and Marc Perry (ref. 7)

77. These fears were not entirely groundless. In 2001, while standing in line to pass through the police barricade and enter the Carnival stands, my small backpack was slashed with a knife or razor blade although nothing was stolen as I was not carrying a wallet.

78. Racial profiling by Havana's police has been noted by numerous observers including Fernandes S. (ref. 7) and Perry. M, (ref. 7). A more in-depth discussion of rumba, race and social control can be found Maya Knaver, L. Racialized culture and translocal counterpublics: rumba and social disorder in New York and Havana. In: Cervantes Rodriguez, M., Grosfoguel R. and Mielants, E. eds. Caribbean Migration to Western Europe and the United States: Essays on Transnationalism, Identity, and Citizenship. Philadelphia: Temple University Press, 2009, pp. 131-168.

79. Personal communication, various.

80. I am referring specifically to works on folkloric performance, not on Afrocuban religion more generally, as there have been several excellent books based on research conducted in the last two decades. There are some excellent articles and book chapters on these themes, based on more recent research including Delgado, K. Spiritual Capital: Foreign Patronage and the Trafficking of Santeria. In: Hernandez-Reguant, A. (ref. 23, pp. 51-67), and a few chapters in Moore, R. Music and Revolution (ref. 3)

81. Yúdice, G. The Expediency of Culture. Minneapolis: University of Minnesota Press, 2003

82. Daniel Rodriguez, interview with author, August 2006.

83. Leyda Oquendo, interview with author, January 2007. 